\title{
THE IMPACTS OF PROTECTED AREAS ON THE LIVELIHOODS OF COMMUNITIES' AROUND THE MOUNT CAMEROON NATIONAL PARK, SOUTH WEST REGION
}

\author{
Mbah Ignatius Ngala ${ }^{1}$, Amahnui George Amenchwi ${ }^{2}$ and Tosam Hycinth Ngong $^{3}$ \\ ${ }^{1}$ Institute of Agricultural Research for Development-IRAD, Abong-Mbang, East Region, Cameroon. \\ ${ }^{2}$ Department of Environmental Science, University of Buea, Cameroon \\ ${ }^{3}$ Higher Institute of Transport and Logistics, University of Bamenda, Cameroon \\ https://doi.org/10.35410/IJAEB.2021.5613
}

\begin{abstract}
The management of protected areas (PAs) has become the cornerstone of biodiversity conservation strategies around the world. There is now widespread acceptance that conservation policies should contribute to poverty alleviation. The focus of the study was to examine the impacts of forest conservation on the livelihoods of people living close to the Mount Cameroon national park (MCNP)in the South West region of Cameroon. Ten villages (Bonakanda, Bokwango, Bwassa, Mayunge, Bomana, Lykoko Mile 14, Bafia, Bakingidi, Etome and Batoke) were sampled from the Buea, Bomboko, Muyuka and West Coast clusters of the Mount Cameroon National park. A random sampling technique was used to select 200 households within a four-kilometre radius distance from the National Park. Questionnaires were selfadministered to household heads who have lived within the study for past fifteen years. The data collected was cleaned, coded and analysed using the statistical package for social science (SPSS) version
\end{abstract}

21. A descriptive statistical technique was carried and responses were summarized and presented in the form of tables, charts and graphs. The findings revealed that the percentage of communities engaged in agriculture reduced from 56\% to $51 \%$ (a $5 \%$ reduction) after the creation of the MCNP. Hunting activities also reduced as result of the creation of the park from $19 \%$ to $11 \%$ ( $8 \%$ reduction) before and after the creation of the MCNP respectively. Respondents who depended on hunting as source of livelihood were greatly affected. Due to restriction of access to forest after the creation of the MCNP, respondents have resorted to other livelihood activities like Aquaculture (3.5\%), Business activities (16.3\%) and private sector employment (16.3\%). Average monthly incomes of respondents have reduced from 78,900 FRS (approximately \$142.02) before the creation of the MCNP park to 74,700 FRS (not significant) ((approximately \$134.46) after the creation of the park. The creation of protected areas to conserve biodiversity have both positive and negative impacts, with impacts unequally distributed within local communities. This study recommends further research on local community involvement in protected area governance and co-management as means to reduce costs of protected areas establishment and their uneven distribution among different groups.

Keywords: Protected areas, Livelihoods, Incomes, National parks. 
Vol. 06, No. 01; 2021

ISSN: $2456-8643$

\section{INTRODUCTION}

The management of protected areas (PAs) has become the cornerstone of biodiversity conservation strategies around the world (Singh et al., 2013). Global conservation of biodiversity resources through land protection has expanded from less than 1 million $\mathrm{km} 2$ in 1970 to an estimated 12.2 million $\mathrm{km} 2$ in 1997. With similar expansion up to 2008, the conserved areas have amounted to about 17 million km2 spread out over more than 100,000 areas (Zimmerer et al., 2014). The impacts of PAs on local poverty both negative and potentially positive have been widely debated (Roe, 2008). Although the global benefits of biodiversity and ecosystem services are well recognized, the costs of PAs may be disproportionately borne by local people (Adams \& Hutton, 2007).

A critical question for conservation policy is whether interventions incur net costs or provide net benefits to the local people who are the most directly affected (CBD, 2008). There is now widespread acceptance that conservation policies should, at the very least, do no harm, and where possible should contribute to poverty alleviation (CBD, 2008). Debates have focused on whether the environmental goals of PAs are compatible with poverty alleviation goals, especially in developing countries (Adams et al., 2004). In developing countries, pressures on natural resources are growing in line with growing human populations (Ayele et al., 2004). Increasingly, the establishment of PAs is being adopted as the most feasible strategy in alleviating undesirable effects induced by those pressures (Ayele et al., 2004). Especially in Africa, local people living near protected areas are trapped between their dependence on resources from these areas to meet their local development aspirations, and international pressure to protect resources of high international value (Van-vliet, 2010).

Cameroon is investing efforts to protect the environment through the creation of PAs while at the same time longing to attain its development objectives of becoming an emergent country in 2035 and reducing poverty levels within the economy. Attaining both objectives is accompanied with conflicts between different ministerial departments and stakeholders (Mbi et al, 2020). This is because Forest and other natural resources provide sources of livelihood opportunities for communities in Cameroon and thus restricting access to forest and these natural resources through PAs affects the source of livelihood of these communities (Mbi et al, 2020).

The Mount Cameroon national park (MCNP) supports one of the richest flora and fauna in continental tropical Africa with high levels of endemism, making it one of the world's biodiversity hotspots. Additionally, the MCNP provides immense socio-economic and cultural benefits to forest fringe communities around the national park (MINFOF, 2010). While the decision on forest management is to ensure protection and conservation of forest resources, for the poor forest users and households, forest is for poverty mitigation. There is limited awareness on the impact of forest conservation on livelihood change and household incomes around the MCNP. Few studies like those of Laird et al, (2011) and Nana \& Tchamadeu, (2014) have investigated other aspects of livelihood and have failed to access the impact of forest protection on livelihood change and household incomes. This study therefore attempts to link the impacts of forest conservation on livelihoods changes and household incomes of people living near the 
MCNP.

\section{MATERIALS AND METHODS}

\section{Study Area}

The study was carried out around the periphery of the Mount Cameroon National park (MCNP) in the South West region of Cameroon. The Mt Cameroon National Park was created through Decree No. 2009/2272 of the Prime Minister on the 18th December 2009. The park has a total surface area of 58,178 ha and is located $4^{\circ} 13^{\prime} \mathrm{N}$ and $9^{\circ} 10^{\prime}$

E. This park is part of one of the eight biodiversity hotspots in the "Gulf of Guinea Forests", with a rich, diverse, and partly endemic flora and fauna. The park stretches from evergreen lowland rain forests near sea level through sub- montane and montane forest to montane and sub-alpine grassland to an altitude of $4,070 \mathrm{~m}$ altitude. The seasons are very well defined. There is a period of heavy rains occurring between the months of June and October, and a dry period extending from November to May. At lower altitudes, the annual rainfall ranges from over $10,000 \mathrm{~mm}$ at Cape Debundscha (second wettest place in the world) to less than 2,000 $\mathrm{mm}$ in the north-east of the massif around Munyenge Metombe. The temperature falls with increasing elevation. For each $100 \mathrm{~m}$ ascent, the average temperature drops by about $0.6^{\circ} \mathrm{C}$. The temperature on the top of Mount Cameroon is chilly $4{ }^{\circ} \mathrm{C}$ when in Limbe at the base it is $32^{\circ} \mathrm{C}$ (MINFOF, 2010).

\section{Description of the Park's peripheries}

The park is located within four sub-divisions: Buea, Muyuka, Mbonge and Idenau. The southern boundary is about $2 \mathrm{~km}$ from the Atlantic oceans and harbors the wettest place in Africa (Dbuncha) which occupies second position in the world. The MCNP is made up of 41 villages bordering it directly. There are cosmopolitan centers almost around the park like Limbe, Mutengene, Buea, Ekona, Muyuka, Munyenge and other petty villages. The MCNP is spatially divided into four cluster conservation zones of the MCNP' which comprise 41 villages. They include the Buea cluster in the South and parts of the East, consisting of 13 villages, the Bomboko cluster in the North east and North west areas of the Park, consisting of 12 villages, the Muyuka cluster occupying the East and consisting of 9 villages, and WestCoast cluster consisting of 7 villages (MINFOF, 2010) (Fig 1). 

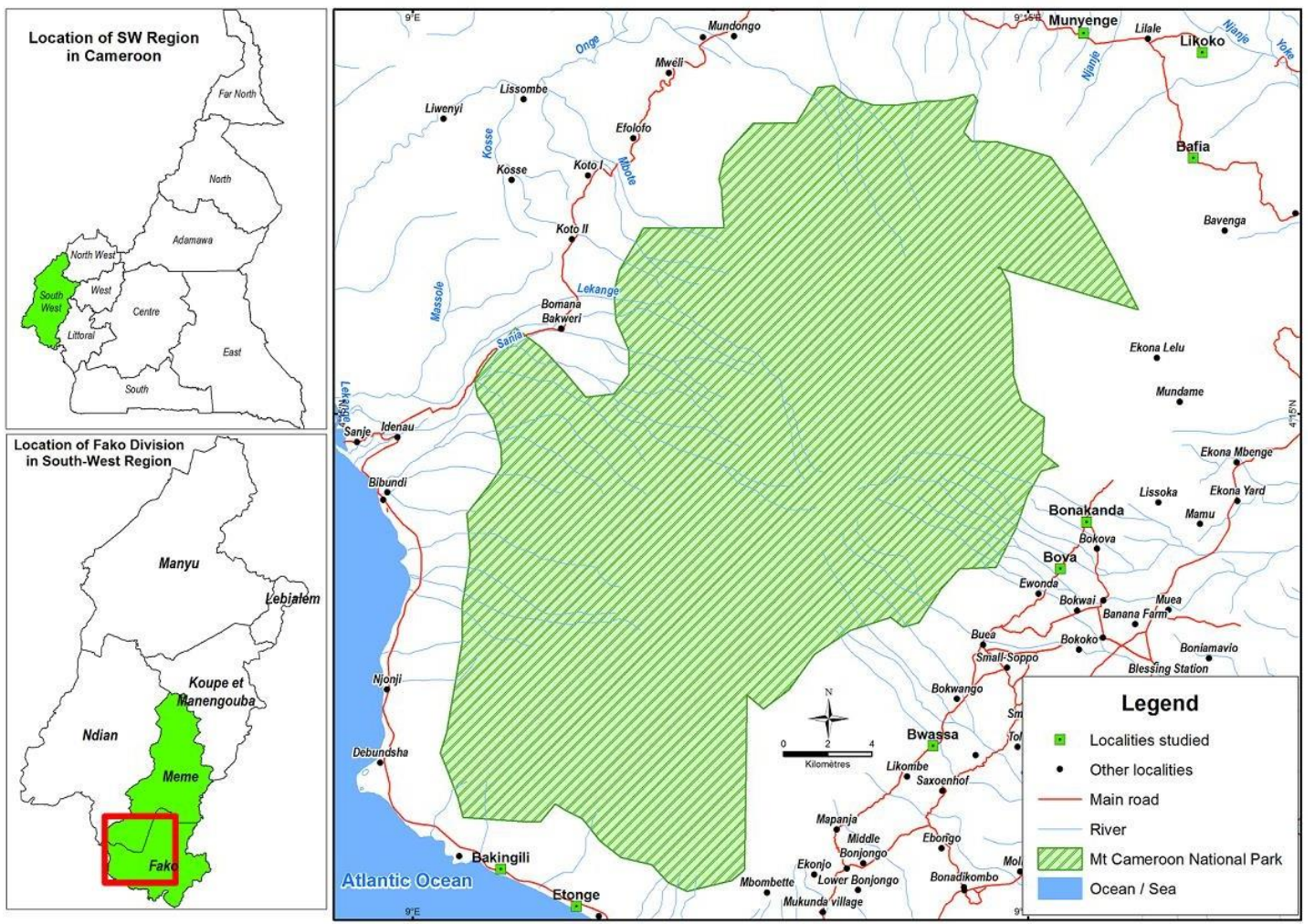

Fig 1: Mount Cameroon and its Peripheral Zone, (Miranda, 2019)

The population of the Mt Cameroon area is estimated to be about 450,000 people of whom twothirds live in urban and peri-urban areas, while the rest in villages. While indigenes are dominant in small villages, large settlements are characterized by a high concentration of non-indigenous population which comprises: Cameroonians from other Regions, Nigerians, Ghanians and other nationals (Konings and Nyamnjoh, 2003). Agriculture is the most important source of livelihood in the Mt. Cameroon area accounting for about $80 \%$ of household income in most villages. Other sources of income include hunting, timber and NTFP exploitation, petty trading, livestock, and few cases of salary earners (MINFOF, 2010).

\section{Data Collection}

\section{Sampling of Location}

Ten Villages from the four clusters around the MCNP were sampled based on their proximity to the national park. Desk study revealed that the closer these areas to the national park, the more intense the impacts of national park on their livelihood and incomes. The choice of villages sampled was also guided by accessibility and the security situation of the villages. The following villages were therefore selected for this study within the clusters (Table 1). 
International Journal of Agriculture, Environment and Bioresearch

Vol. 06, No. 01; 2021

ISSN: $2456-8643$

Table 1: Sample communities used in the study

\begin{tabular}{|c|c|c|c|}
\hline Buea Cluster & Bomboko Cluster & Muyuka Cluster & West Coast Cluster \\
\hline Bonakanda & Mayunge & Lykoko Mile 14 & Bakingidi \\
\hline Bokwango & Bomana & Bafia & $\begin{array}{c}\text { Etom } \\
\mathrm{e}\end{array}$ \\
\hline Bwassa & & & $\begin{array}{c}\text { Batok } \\
\mathrm{e}\end{array}$ \\
\hline
\end{tabular}

Sampling of Respondents (Households)

Households were respondents of this research and thus they were the unit of analysis for this research.For this study, a sample of 200 households was considered appropriate. The respondents identified and selected was within a four- kilometre distance from the National Park. The respondents were selected following the recommendations of Kiragu, (2002) and Kenya Indigenous Forest Conservation Programme, (KIFCON), (1994). Kiragu, (2002) asserts that the impact and interaction of the community with the forest decreases with the distance from the forest while KIFCON, (1994) also indicated that the greatest interaction of the community with the forest is by living within the radius of $5 \mathrm{~km}$ from the forest. A random sampling technique was used to identify and pick households living around the MCNP and within a $5 \mathrm{~km}$ radius.

\section{Questionnaire Administration}

A total of 200 questionnaires were sent out, at the end of the exercise to be administered in the ten communities sampled. Ten questionnaires had to be administered in each community. Open ended and closed questions were used to allow for qualitative discussions with the household concern and hence provide enough qualitative data. Questions in the questionnaires were designed to achieve the specific objectives of the study. Data was collected within the months of October and November 2020.

Add a samples questionnaire and respondent percentages

\section{Data Analysis}

After the administration of questionnaires, the data was cleaned and coded into the statistical software for social science (SPSS) version 21. Questionnaires that were not properly completed were discarded. A basic descriptive statistical analysis was carried out on SPSS and the results of the study were presented in the form of tables, graphs and chat.

\section{RESULTS}

Out of 200 questionnaires sent out for data collection, 184 were finally administered giving a respondent rate of $92 \%$. A majority of respondents for this study were within the ages of 41 and 50 years $(45.80 \%)$ while the least number of respondents were above the age of 60 years $(12 \%)$. $38.9 \%$ of respondents from this study were males while $61.1 \%$ were females. Show in a table format 
Impacts of forest protection on livelihoods sources.

Findings reveal that main source of livelihood prior to the creation of the MCNP was agriculture $(56 \%)$ while the least source of livelihood was private sector (4\%) (fig 2).

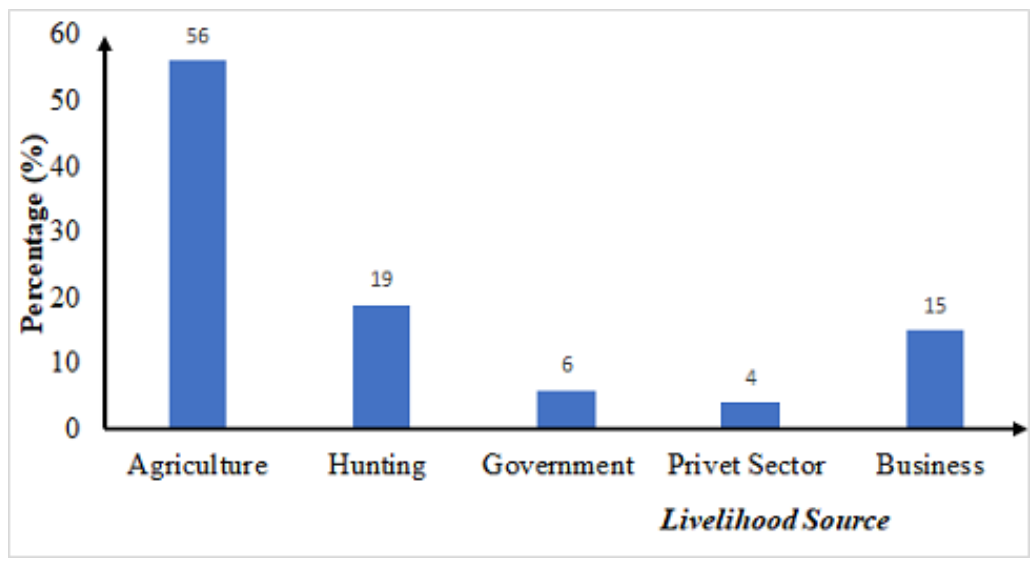

Fig 2: Sources of Livelihood prior to forest resource protection in the MCNP.

Farming still remains the highest source of livelihood after the creation of the Mount Cameroon national park but the percentage of communities engaged in farming have reduced from $56 \%$ to $51 \%$ (a 5\% reduction). Hunting activities also reduced as result of the creation of the park from $19 \%$ to $11 \%$ ( $8 \%$ reduction) before and after the creation of the MCNP respectively. The percentage of communities engaged business (16.3\%) and private sector employment (11\%) witnessed an increase while fishing (3.5) emerged as a source of livelihood (Fig 3). Respondents who depended on hunting as source of livelihood has been more affected than any other group.

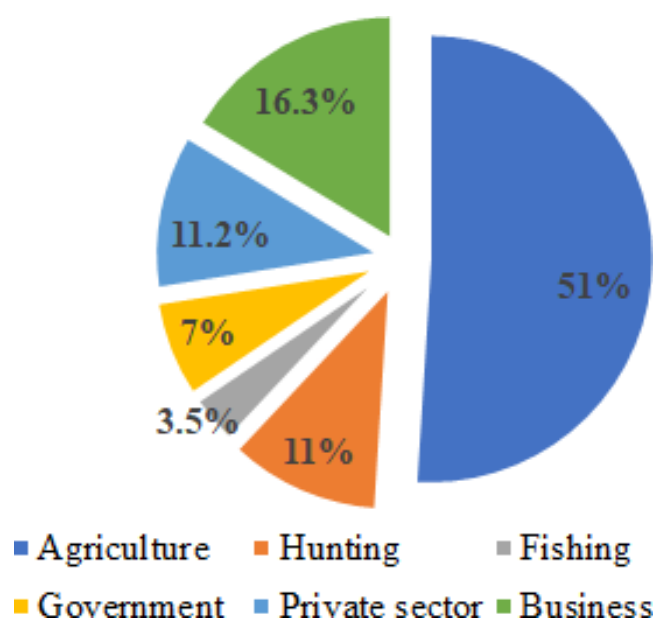

Fig 3: Livelihood Sources after forest resource Protection in MCNP 
Results also show that $23.5 \%$ of respondents have changed their source of livelihood as result of forest protection while $76.5 \%$ of respondents have not change their source of livelihood due to forest resource protection (fig 4).

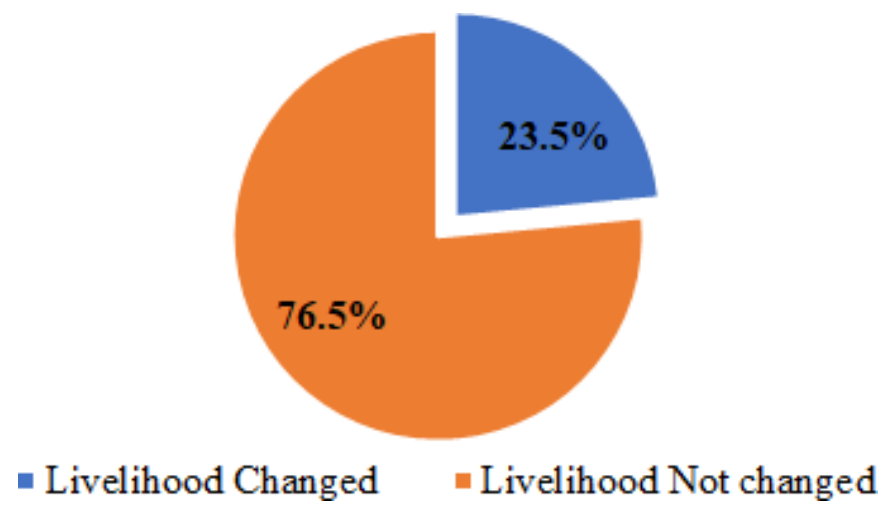

Fig 4: Impacts of forest protection on the changes in livelihood.

For respondents who change livelihood source, their reasons for this change were either because of forest restriction by park authorities (53\%), new jobs provided by park authorities $(20 \%)$ or other reasons (27\%) not related to the creation of the National park (fig 5).

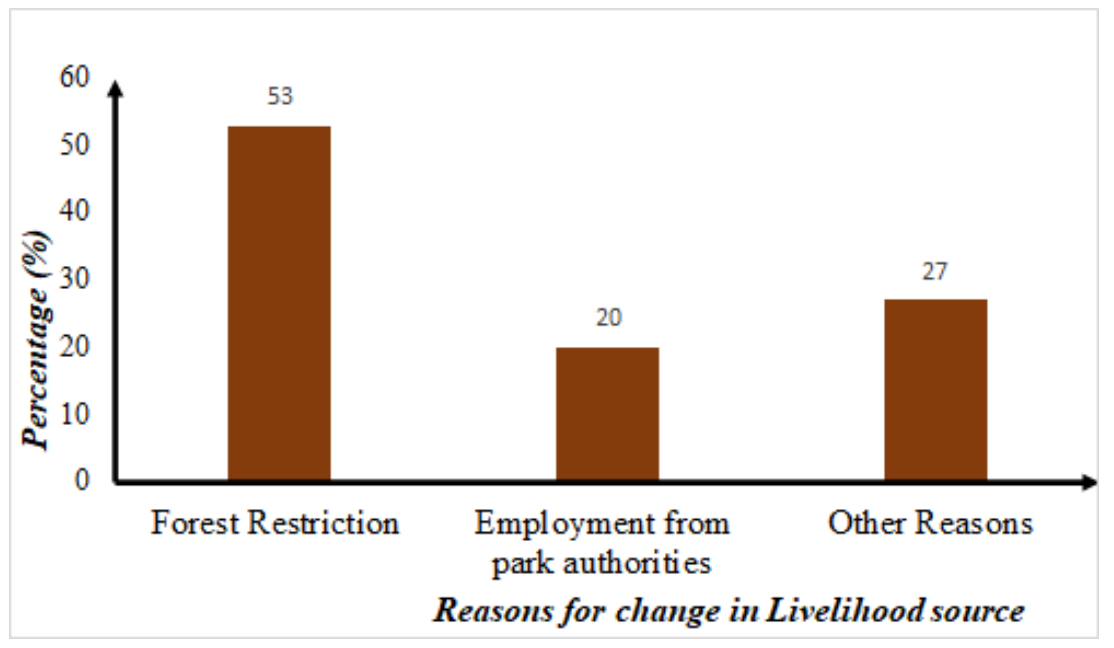

Fig 5: Reasons for a change in Livelihood Source after the creation of MCNP

Impacts of MCNP on household incomes

Further findings of this study also reveal that $57 \%$ of respondents have experience a change in their income due to reasons related to the creation of the national park while $43 \%$ of respondents have not witness a change in their incomes.

Furthermore, results show that average monthly incomes of respondents have reduced from 78,900 FRS (approximately \$142.02) before the creation of the park to 74,700 FRS 
((approximately \$134.46) after the creation of the park (Fig 6). Average monthly incomes reduced by 4,200 FRS (approximately $\$ 7.56$ ) as a result of the creation of the national park according to findings.

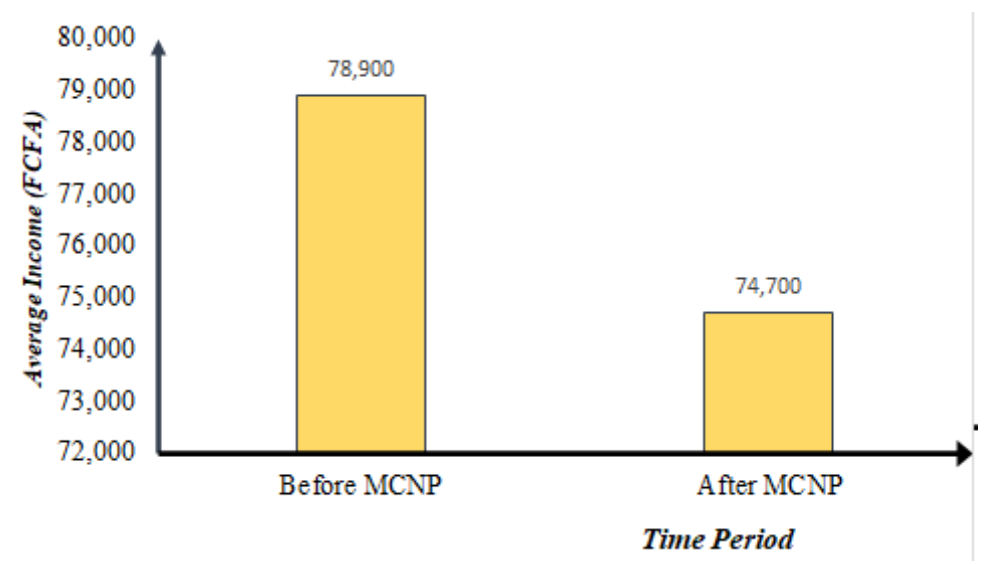

Fig 6: Impacts of the MCNP on average incomes

\section{DISCUSSION}

Prior to the establishment of the MCNP, 56\% percentage of communities living adjacent the national park depended solely on agriculture as a means of livelihood. A very limited fraction of the communities (4\%), depended on the private sector as a means of their livelihood sustenance. Just like in many rural communities in Cameroon, agriculture (especially small-scale farming) is the main source of livelihood and the backbone of rural economies (Molua, 2015). Aside from agriculture, a good number of communities (19\%) were hunters who engaged into hunting activities in the national park to hunt bush meat which was often being traded to neighbouring peri-urban and urban areas near the national park like Limbe, Buea, Mutegene and Tiko. After the creation of the MCNP, the percentage of communities involve in agriculture and hunting reduced to $51 \%$ and $11 \%$ percent respectively (a $5 \%$ and $8 \%$ reduction respectively). This change may have occurred to as a result of restriction of access into and around the park boundaries thereby depriving communities of their source of livelihood. The results of this study are almost similar to the findings of McElwee, (2010) who noted the negative effects of protected areas on agriculturalist in central Vietnam. Just like in the Mount Cameroon national park, McElwee, (2010) noted forest restriction around national parks in central Vietnam which led to a reduction in farm seizes and low yields causing communities to switch livelihood sources. Vedeld et al., (2012) also noted Increasing land scarcity for difference livelihood sources like agriculture and NTFP as a result of the protection of the Mikumi National Park in Tanzania mounting pressures on resource use conflicts which is similar to the findings of this study.

However, findings of Clements et al., (2014) revealed that households bordering protected areas in Cambodia were significantly better off after forest protection and had greater rice harvests, 
Vol. 06, No. 01; 2021

ISSN: $2456-8643$

because they had more secure access to land and forest resources. This is not in line with findings of this study in the MCNP. The differences in the results of these two areas could have been as a result of management objectives and plans for protected areas in Cameroon and Cambodia. Generally, when the management of a protected area is integrated with livelihood improvement, communities closer to these protected areas will benefit more in the form of livelihood diversification and the payment from Ecosystem services as a result of the protection of the resource (Agrawal\& Redford, 2006). However, when livelihood improvement is not considered an objective and priority in the management objective of a protected area, communities will be displaced and may lose their livelihood sources as result of forest protection which often leads to tension between the park management and communities (Newmark, 2013). In such situations, conservation objectives may not be realized.

Findings of this research also reveal that forest protection led to the reduction of average monthly household incomes by 4,200frs (\$7.98). This reduction in income may have occurred as a result of limited access to forest and its resources around the national park boundaries where communities depended on for their livelihood activities such as farming and hunting. This is different from the results of Child and Dalal-Clayton, (2004) who noted that the creation of South Laungwa National park led to the creation of two hunting concessions where communities earned an annual revenue of US\$230,000 for 50,000 residents. Incomes earned from these hunting concessions were further used for local community development projects. The creation of protected areas requires deep planning and provision of alternative livelihood and income sources for communities whose livelihoods strategies formally relied on the protected area or areas just around the protected area.

\section{CONCLUSION AND RECOMMENDATION}

The creation of the MCNP has led to changes in livelihood sources for communities living close to the Mount Cameroon. The percentage of residents who carry out agricultural and hunting activities as a source of livelihood has reduced by5\% and $8 \%$ respectively after the creation of the MCNP while residents involve in private sector employment and business sector have increase by $7.2 \%$ and $1.5 \%$ respectively. These changes further led to reduction in average incomes by 4,200 frs $(\$ 7.98)$.

The creation of PAs to conserve biodiversity can have both positive and negative impacts, with impacts unequally distributed within local communities. Authors recommended further research shift towards local community involvement in protected area governance and co-management as means to reduce costs of PAs establishment and their uneven distribution.

\section{Acknowledgement}

Authors will like to thank the chiefs and the entire communities used in this study for their responses towards research. Authors will like to thank the management of the MCNP for providing them with enough insights on the national park area and for helping with a criterion for the sampling of communities used in this study. 
Vol. 06, No. 01; 2021

ISSN: $2456-8643$

\section{REFERENCES}

Adams, W. M., \& Hutton, J. (2007). People, parks and poverty: Politicalecology and biodiversity conservation. Conservation and Society, 5,147-183.

Adams, W. M., Aveling, R., Brockington, D., Dickson, B., Elliott, J.,utton, J., et al. (2004).

Biodiversity conservation and the eradicationof poverty. Science, 306, 1146-1149.

Agrawal, A., \& Redford, K. H. (2006). Poverty, development andbiodiversity conservation:

Shooting in the dark? WCS working paperno. 26. New York: Wildlife Conservation Society.

Ayele, K., \&Kideghesho, J. (2004). Community-based Land Use Planning for Conservation and Development. In WEnt-GTZ Training Course. Ethiopia.

Clements, T., Suon, S., Wilkie, D. S., \& Milner-Gulland, E. J. (2014). Impacts of protected areas on local livelihoods in Cambodia. World development, 64, S125-S134.

Child, B., \&Dalal-Clayton, B. (2004). Transforming approaches to CBNRM: Learning from the Luangwa experience in Zambia. Getting biodiversity projects to work: Towards more effective conservation and development, 256-289.

CBD (Convention on Biological Diversity). 2008. Decision IX/18. 9thConference of the Parties to the Convention on Biological Diversity,Bonn.

CBD. (2008). Ninth conference of the parties to the convention onbiological diversity, decision IX/18, Bonn. Convention on BiologicalDiversity.

Konings, P., \&Nyamnjoh, F. B. (2003). Negotiating an Anglophone identity: A study of the politics of recognition and representation in Cameroon (Vol. 1). Brill.

Kenya Indigenous Forest Conservation Programme. (1994). A Review of KIFCON Phase I and Identification of Gaps Arising from Programme Termination: Proceedings of a Workshop at Safari Park Hotel, Nairobi, April 1994. KIFCON.

KIRAGU, S. W. (2002). Community participation in forest resources management in Mt. Elgon forest and itsenvirons (Doctoral dissertation).

Laird, S. A., Awung, G. L., Lysinge, R. J., \&Ndive, L. E. (2011). The interweave of people and place: biocultural diversity in migrant and indigenous livelihoods around Mount Cameroon. International Forestry Review, 13(3), 275-293

Mbi, B. M. T., \&Lebga, A. K. (2020). Protected Areas in Cameroon at the Mercy of the 2035 Emergent Project. In National Parks. IntechOpen.

McElwee, P. D. (2010). Resource use among rural agricultural households near protected areas in

Vietnam: the social costs of conservation and implications for enforcement. Environmental management, 45(1), 113-131.

Ministry of Forestry and Wildlife (MINFOF) (2010). Database of community forests.

Minisitry of Forestry and Wildlife, Yaoundé.

Molua, E. L. (2015). An empirical assessment of the impact of climate change on smallholder agriculture in Cameroon. Global and Planetary Change, 67(3-4), 205-208.

Nana, E. D., \&Tchamadeu, N. N. (2014). Socio-economic impacts of protected areas on people living close to the mount Cameroon National Park. Parks, 20(2), 129-137.

Newmark, W. D., Leonard, N. L., Sariko, H. I., \&Gamassa, D. G. M. (2013). Conservation attitudes of local people living adjacent to five protected areas in Tanzania. Biological conservation, 63(2), 177-183. 
Vol. 06, No. 01; 2021

ISSN: $2456-8643$

Roe, D. (2008). The origins and evolution of the conservation-povertydebate: A review of key literature, events and policy processes. Oryx,42, 491-503.

Sims, K. R. E. (2010). Conservation and development: Evidence from Thai protected areas. Journal of Environmental Economics and Management, 60, 94-114.

Singh, R., Channa, P., Sovanna, P., Chanratana, P., Ryan, G., \& Wright, M. (2013). The Serengeti of Asia: conservation in two major protected areas of the eastern plainslandscape protected area complex, Cambodia. PARKS, 19, 23-33.

Van Vliet, N. (2010). Participatory vulnerability assessment in the context of conservation and development projects: a case study of local communities in Southwest Cameroon. Ecology and Society, 15(2).

Vedeld, P., Jumane, A., Wapalila, G., \&Songorwa, A. (2012). Protected areas, poverty and conflicts: A livelihood case study of Mikumi National Park, Tanzania. Forest policy and economics, 21, 20-31.

Zimmerer, K. S., Galt, R. E., \& Buck, M. V. (2004). Globalization and multi-spatial trends in the coverage of protected-area conservation (1980-2000). Ambio: A Journal of the Human Environment, 33(8), 520-529. 